\title{
PENGARUH PELATIHAN DAN PEMBERIAN INSENTIF TERHADAP KINERJA KARYAWAN DI ELLENA SKIN CARE SOLO
}

\author{
Ismani $^{1}$, Dasmadi ${ }^{2}$, Heri Purwanto ${ }^{3}$ \\ Fakultas Ekonomi Manajemen \\ Universitas Boyolali \\ Jln. Pandanaran No. 405 Boyolali
}

E-mail : ismanisiwi@gmail.com ${ }^{1)}$, Dasmadi82@gmail.com ${ }^{2)}$, Hariharipoer@yahoo.co.id ${ }^{3)}$

\begin{abstract}
ABSTRAK
Peluang bisnis bagi para pemimpin bisnis kecantikan dunia, khususnya klinik kecantikan, tingginya kebutuhan akan perawatan kecantikan menjadikan peluang bisnis bagi mereka. Klinik kecantikan saling bersaing untuk menunjukkan keunggulan kompetitifnya melalui upaya kreatif, inovatif, bekerja secara efektif dan efisien sehingga produk dan layanan yang mereka hasilkan menjadi pilihan bagi banyak pelanggan. Berdasarkan identifikasi masalah dan batasan masalah dalam penelitian ini, maka dirumuskan masalah apakah pelatihan dan insentif berpengaruh terhadap kinerja karyawan di Ellena Skin Care Solo ?. Jenis penelitian berdasarkan pendekatannya adalah penelitian kuantitatif. Penelitian ini menggunakan desain korelasional yaitu hubungan antara variabel bebas $\mathrm{X} 1$, dan $\mathrm{X} 2$ terhadap variabel terikat $\mathrm{Y}$. Populasi penelitian ini adalah seluruh karyawan Ellena Skin Care Solo. Teknik pengambilan sampel dalam penelitian ini adalah total sampling, sehingga jumlah sampel yang diambil dalam penelitian ini sebanyak 30 responden. Penelitian ini menggunakan pendekatan analisis data regresi linier berganda. Berdasarkan hasil penelitian diketahui bahwa pelatihan kerja berpengaruh signifikan terhadap kinerja karyawan, hal ini dikarenakan Ellena Skin Care Solo merupakan perusahaan yang bergerak di bidang jasa perawatan tubuh dan wajah, sehingga setiap karyawan yang bekerja di Ellena Skin Care Solo selalu mendapat pelatihan kerja untuk memberikan bekal ketrampilan bagi karyawan dalam memberikan pelayanan kepada pelanggan, sehingga $\mathrm{H} 1$ diterima. Insentif tidak berpengaruh signifikan terhadap kinerja karyawan Ellena Skin Care Solo hal ini dikarenakan untuk mendapatkan insentif, karyawan diharuskan bekerja dengan waktu ekstra atau porsi pekerjaan yang lebih besar, hal ini dianggap memberikan insentif hanya sebagai pengganti kelelahan, sehingga $\mathrm{H} 2$ ditolak.
\end{abstract}

\section{Kata kunci: pelatihan, insentif, kinerja karyawan, Ellena Skin Care}

\section{ABSTRACT}

Business opportunities for the world beauty business leaders, especially beauty clinics, the high need for beauty care makes a business opportunity for them. Beauty clinics compete with each other to show their competitive advantage through creative, innovative efforts, work effectively and efficiently so that the products and services they produce become choices for many customers. Based on the problem identification and problem limitation in this study, the problem was formulated whether the training and incentive had an effect on the performance of employees at Ellena Skin Care Solo?. This type of research based on its approach is quantitative research. This study uses a correlational design that is the relationship between independent variables $X_{1}$, and $X_{2}$ on the dependent variable Y. The population of this study is all employees of Ellena Skin Care Solo. The sampling technique in this study was total sampling, so the number of samples taken in this study were 30 respondents. This study uses a multiple linear regression data analysis approach. Based on the results of the study it is known that job training has a significant effect on employee performance, this is because Ellena Skin Care Solo is a company engaged in body and facial care services, so that every employee who works at Ellena Skin Care Solo always gets job training to 
provide supplies skills for employees in providing services to customers, so $H_{1}$ is accepted. Incentives do not significantly influence the performance of Ellena Skin Care Solo employees, this is due to get incentives, employees are required to work with extra time or a larger portion of work, this is considered to provide incentives only as a substitute for fatigue, so $\mathrm{H}_{2}$ is rejected.

Keywords : training, incentives, employee performance, Ellena Skin Care

\section{PENDAHULUAN}

\section{Latar Belakang}

Perkembangan ekonomi,teknologi dan budaya masyarakat yang semakin meningkat pada era ini menyebabkan perubahan jaman menuju ke era modernisasi. Keberlangsungan hidup perusahaan sangat ditentukan oleh kinerja perusahaan itu sendiri, dimana kinerja karyawan merupakan salah satu faktor terpentingnya.Para manajer dari perusahaan-perusahaan multinasional yang sangat besar hingga perusahaan-perusahaan domestik yang sangat kecil menyatakan bahwa mengelola manusia secara efektif sangatlah penting untuk bisa sukses dalam pasar yang sangat kompetitif saat ini. Untuk memperoleh dan meningkatkan kinerja karyawan yang baik seorang manajer harus mengetahui dan melayani kebutuhan karyawannya. Hal ini tidak hanya dilakukan melalui cara penarikan kerja yang tepat, tetapi juga harus didukung oleh usaha yang lain.

Di Solo telah banyak berdiri perusahaan khususnya Klinik Kecantikan, mereka saling bersaing dan berkompetisi dalam bidang kualitas pelayanan, produk dan harga yang kompetitif, salah satunya Klinik Kecantikan Ellena Skin Care yang berlamat di J1 Dr. Setiabudi No 80.

Kinerja adalah keluaran yang dihasilkan oleh fungsi-fungsi atau indikator-indikator suatu pekerjaan atau suatu profesi dalam waktu tertentu (Wirawan, 2009 : 5). Dessler dalam Martcahyo,dkk (2012) mengatakan kinerja merupakan prestasi kerja yaitu perbandingan antara hasil kerja yang nyata dengan standar kerja yang ditetapkan.

Berbagai pendekatan yang berbeda telah banyak dilakukan untuk mengelola sumber daya manusia. Hal tersebut perlu dilakukan untuk merespon adanya perkembangan teknologi. Salah satunya dengan mengadakan pelatihan. Pelatihan adalah proses mengajarkan karyawan baru atau yang ada sekarang, ketrampilan dasar yang mereka butuhkan untuk menjalankan pekerjaan mereka Dessler, 2009. Pelatihan merupakan salah satu usaha dalam meningkatkan mutu sumber daya manusia dalam dunia kerja. Karyawan, baik yang baru ataupun yang sudah bekerja perlu mengikuti pelatihan karena adanya tuntutan pekerjaan yang dapat berubah akibat perubahan lingkungan kerja, strategi, dan lain sebagainya. Pelatihan juga dapat diartikan sebagai usaha yang terencana dari perusahaan untuk meningkatkan pengetahuan, keterampilan dan kemampuan karyawan. Dengan pelaksanaan pelatihan yang tepat, maka perusahaan diharapkan dapat memperbaiki efektivitas kerja karyawan dalam mencapai hasil-hasil kerja yang telah ditetapkan.

Selain pelatihan pemberian insentif juga dapat meningkatkan motivasi yang mendorong para pegawai untuk bekerja dengan kemampuan yang optimal, yang dimaksudkan adalah pendapatan ekstra di luar gaji atau upah yang telah ditentukan. Pemberian insentif dimaksudkan agar dapat memenuhi kebutuhan para pegawai dan keluarga mereka. Insentif dapat dirumuskan sebagai balas jasa yang memadai kepada pegawai yang prestasinya melebihi standar yang telah ditetapkan, Insentif diharapkan dapat mendorong pegawai untuk bekerja lebih baik agar kinerja pegawai dapat meningkat sehingga stabilitas perusahaan dapat selalu terjaga.

Dari uraian yang telah dijelaskan diatas maka penulis bermaksud untuk melakukan penelitian dengan judul "Pengaruh Pelatihan Dan Pemberian Insentif Terhadap Kinerja Karyawan Di Ellena Skin Care Solo".

\section{Perumusan Masalah}

Berdasarkan latar belakang yang telah diuraikan diatas maka penulis dapat merumuskan permasalah sebagai berikut:

1. Bagaimana pengaruh pelatihan terhadap kinerja karyawan Ellena Skin Care Solo?

2. Apakah pemberian insentif berpengaruh terhadap kinerja karyawan di Ellena Skin Care Solo?

\section{Tujuan penelitian}


Dalam penyusunan jurnal ini penulis memiliki tujuan dilakukannya penelitian yang terkait dengan perumusan masalah diatas, yaitu:

1. Mengetahui pengaruh pelatihan terhadap kinerja karyawan di Ellena Skin Care Solo.

2. Mengetahui pengaruh pemberian insentif terhadap kinerja Karyawan di Ellena Skin Care solo.

\section{TINJAUAN PUSTAKA}

\section{Klinik Kecantikan}

Menurut Kamus Besar Bahasa Indonesia edisi empat 2015:705 Klinik merupakan organisasi kesehatan yang bergerak dalam penyediaan pelayanan kesehatan kuratif diagnosis dan pengobatan, biasanya terhadap satu macam gangguan kesehatan. Menurut Kamus Besar Bahasa Indonesia, cantik atau kecantikan adalah keelokan, kemolekan. Kecantikan terdiri dari dua macam yaitu, kecantikan dalam (inner beauty) dan kecantikan luar (outer beauty). Outer beauty atau kecantikan luar memang dapat direfleksikan dengan bentuk wajah yang ayu, cantik, dan enak dilihat. Sedangkan inner beauty adalah personality (kepribadian) seorang perempuan, bagaimana sikapnya terhadap siapa saja, bagaimana keanggunan atau juga sisi feminine yang diimpresikan oleh perempuan.

Berdasarkan pengertian diatas klinik kecantikan dapat diartikan sebagai sebuah klinik yang menawarkan jasa pelayanan perawatan baik pada kulit, rambut, kuku dan menawarkan pelayanan jasa di bidang perawatan kesehatan dan kecantikan kulit, rambut, kuku, dan lainnya. Beberapa klinik kecantikan yang sekarang banyak dijumpai diwilayah kota adalah klinik kecantikan yang mengkombinasikan pelayanan kecantikan wajah maupun tubuh, dan konsultasi kesehatan kulit, serta pelayanan tambahan seperti spa, massage, dan manicure pedicure. Klinik kecantikan juga berfungsi sebagai tempat untuk melakukan konsultasi dan perawatan terhadap tubuh, wajah, kulit, rambut dan kuku dengan dilakukan oleh ahli kecantikan dan dokter spesialis. Mengembalikan kebugaran tubuh serta mempercantik penampilan dari setiap pengunjung yang menggunakan fasilitas dari klinik kecantikan.

\section{Pengertian Jasa}

Menurut Lupiyoadi 2013:5 Jasa adalah semua aktivitas ekonomi yang hasilnya tidak merupakan produk dalam bentuk fisik atau konstruksi, yang biasanya dikonsumsi pada saat yang sama dengan waktu yang dihasilkan dan memberikan nilai tambah (seperti misalnya kenyamanan, hiburan kesenangan atau kesehatan) atau pemecahan akan masalah yang dihadapi konsumen.

Jasa dapat juga diartikan sebagai suatu kinerja atau tindakan tidak kasat mata dari suatu pihak ke pihak lain. Pada umumnya jasa diproduksi dan dikonsumsikan secara bersamaan sehingga interaksi antara pemberi dengan penerima jasa saling mempengaruhi hasil jasa tersebut.

\section{Pelayanan}

Menurut Moenir, A.S. 2010 Pelayanan adalah kegiatan yang dilakukan oleh seseorang atau sekelompok orang dengan landasan faktor materi melalui sistem, prosedur dan metode tertentu dalam rangka usaha memenuhi kepentingan orang lain sesuai dengan haknya. Pelayanan hakikatnya adalah serangkaian kegiatan, karena itu pelayanan merupakan sebuah proses. Sebagai proses, pelayanan berlangsung secara rutin dan berkesinambungan, meliputi seluruh kehidupan orang dalam masyarakat. Pelayanan juga dapat diartikan sebagai suatu aktivitas atau serangkaian aktivitas yang bersifat tidak kasat mata atau tidak dapat diraba yang terjadi sebagai akibat adanya interaksi antara konsumen dengan karyawan atau hal-hal lain yang di sediakan oleh perusahaan pemberi pelayanan yang dimaksudkan untuk memecahkan permasalahan konsumen atau pelanggan.

\section{Karyawan}

Menurut Hasibuan 2009 Karyawan adalah setiap orang yang bekerja dengan menjual tenaganya fisik dan pikiran kepada suatu perusahaan dan memperoleh balas jasa yang sesuai dengan perjanjian. Sedangkan Para pegawai adalah aset organisasi yang paling berharga. Pengetahuan dan keahlian mereka mempengaruhi kualitas barang dan jasa yang diberikan ke para pelanggan. Di dalam perusahaan manufaktur, dimana tenaga kerja biasanya hanya mencerminkan sebagian dari total biaya langsung, para pegawai adalah penggerak biaya dalam hal kualitas kerja mereka mempengaruhi baik produktivitas keseluruhan maupun tingkat kecacatan produk.

\section{Pelatihan}


Menurut Sjafri Mangkuprawira 2011:134 Pelatihan bagi karyawan merupakan sebuah proses mengajarkan pengetahuan dan keahlian tertentu, serta sikap agar karyawan semakin terampil dan mampu melaksanakan tanggung jawabnya dengan semakin baik, sesuai dengan standar. Biasanya pelatihan merujuk pada pengembangan keterampilan bekerja (vocational) yang dapat digunakan dengan segera. Pada dasarnya tujuan pelatihan yaitu ingin mengembangkan karyawan untuk terampil, terdidik, dan terlatih secara professional dan siap pakai dalam bidangnya masing-masing.

Dengan adanya pelatihan dalam suatu perusahaan atau organisasi, maka dapat dimungkinkan terjadi peningkatan produktivitas kerja, yang juga dikarenakan para karyawan telah memiliki modal atau kemampuan yang cukup untuk mencapai tujuan perusahaan atau organisasi. Perusahaan merasa memerlukan pelatihan bagi karyawannya baik karyawan lama maupun karyawan baru guna mencapai tujuannya. Pelatihan memberikan berbagai manfaat, baik kepada perusahaan maupun karyawan itu sendiri. Bagi karyawan, pelatihan memberi manfaat seperti tambahan pengetahuan, keterampilan kerja, peningkatan prestasi kerja dan sebagainya. Sedangkan bagi perusahaan mereka juga memperoleh manfaat lebih seperti terjaganya stabilitas perusahaan dan karyawan.

Pelatihan yang baik juga membawa manfaat antara lain yang dikemukakan oleh Noe, Hollenbeck, Gerhart, Wright yaitu meningkatkan pengetahuan para karyawan atas budaya dan para pesaing luar, membantu para karyawan yang mempunyai keahlian untuk bekerja dengan teknologi baru, membantu para karyawan untuk memahami bagaimana bekerja secara efektif dalam tim untuk menghasilkan jasa dan produk yang berkualitas, memastikan bahwa budaya perusahaan menekankan pada inovasi, kreativitas dan pembelajaran, menjamin keselamatan dengan memberikan cara-cara baru bagi para karyawan untuk memberikan cara-cara baru bagi para karyawan untuk memberikan kontribusi bagi perusahaan pada saat pekerjaan dan kepentingan mereka berubah atau pada saat keahlian mereka menjadi absolut, mempersiapkan para karyawan untuk dapat menerima dan bekerja secara lebih efektif satu sama lainnya.

\section{Kerangka Pemikiran}

Berdasarkan landasan teori dan hasil penelitian terdahulu maka, kerangka pemikiran pada penelitian ini adalah sebagai berikut :

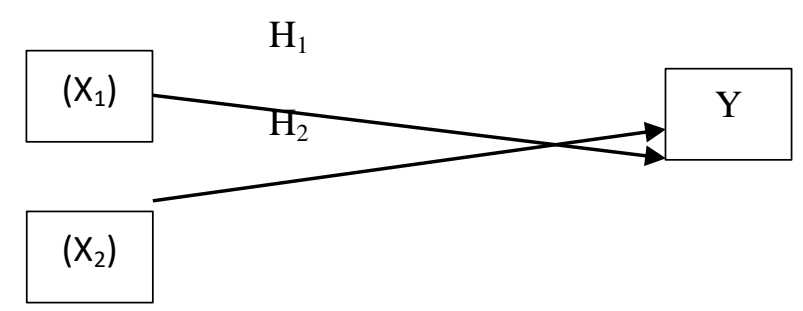

Keterangan :

$\mathrm{X}_{1} \quad$ : Pelatihan

$\mathrm{X}_{2} \quad$ : Insentif

Y : Kinerja Karyawan

$\mathrm{H}_{1} \quad$ : Pengaruh Variabel $\mathrm{X}_{1}$ terhadap $\mathrm{Y}$

$\mathrm{H}_{2}$ : Pengaruh Variabel $\mathrm{X}_{2}$ terhadap $\mathrm{Y}$.

Hipotesis

Hipotesis merupakan anggapan dasar yang kemudian masih harus di uji kebenarannya. Dalam kaitannya dengan pelatihan dan pemberian insentif terhadap kinerja karyawan diatas, maka rumusan hipotesis dalam penelitian ini adalah :
$\mathrm{H}_{1}$ : Pelatihan kerja berpengaruh positif terhadap kinerja karyawan perusahaan. Pemberian insentif berpengaruh positif
$\mathrm{H}_{2}$ : terhadap kinerja karyawan perusahaan.

\section{METODE PENELITIAN Metode Penelitian}

Untuk menarik kesimpulan dari data yang dikumpulkan, maka penulis menggunakan metode kuantitatif yang bertujuan untuk menguji hipotesis serta menggambarkan keadaan-keadaan dari objek dengan hubungan variabel yang diteliti dilapangan. Kemudian terhadap permasalahan yang timbul akan ditinjau dan dianalisis secara mendalam dengan didasarkan fakta hubungan antara variable yang diteliti. Variabel yang akan diuji 
yaitu variable independent meliputi pelatihan dan insentif sedangkan variabel dependentnya adalah kinerja karyawan.

\section{Obyek Penelitian}

Menurut Sugiyono (2016:13) obyek penelitian adalah sasaran ilimiah untuk mendapatkan data dengan tujuan dan kegunaan tertentu sesuatu hak obyektif, valid dan reliable tentang suatu hal. Penelitian yang penulis lakukan bertempat di Klinik Kecantikan Ellena Skin Care yang beralamat di Jalan Dr Setiabudi No. 80 Solo.

\section{Populasi dan Sampel}

Menurut sugiyono (2013:117) Populasi adalah wilayah generalisasi yang terdiri dari obyek atau subyek yang mempunyai kualitas dan karakteristik tertentu yang ditetapkan oleh peneliti untuk dipelajari dan ditarik kesimpulan. Populasi pada penelitian ini adalah seluruh karyawan Ellena Skin Care Solo.

Menurut sugiyono (2012:116) sampel adalah bagian dari jumlah dan karakteristik yang dimiliki oleh populasi tersebut. Pengambilan sampel dilakukan dengan metode random sampling yaitu pengambilan anggota sampel dari populasi dilakukan secara acak dan dimana tiap unsur yang membentuk populasi diberi kesempatan yang sama untuk terpilih menjadi sampel. Dalam penarikan sample maka jumlahnya harus representative untuk nantinya hasil bisa digeneralisasi. Untuk memperkecil ruang lingkup serta keterbatasan kemampuan, maka penulis memutuskan untuk memilih keresponden di Rumah Kecantikan Ellena Skin Care Solo berjumlah 30 orang. Hal ini sebagaimana dikemukakan oleh Baley dalam Mahmud (2011: 159) yang menyatakan bahwa untuk penelitian yang menggunakan analisis data statistik, ukuran sampel paling minimum adalah 30 .

\section{Definisi Operasional Variabel}

1. Variabel Independen / Variabel Bebas (X)

Menurut Sugiyono (2016: 39) pengertian variabel independen adalah variabel yang mempengaruhi atau yang menjadi sebab perubahannya atau timbulnya variabel dependen (terikat). Dalam penelitian ini yang menjadi variabel independen adalah Pelatihan, dan Insentif

2. Variabel Dependen / Variabel Terikat (Y)

Menurut Sugiyono (2016: 59) pengertian variabel dependen dalam bahasa Indonesia sering disebut variabel terikat. Variabel terikat merupakan variabel yang dipengaruhi atau yang menjadi akibat, karena adanya variabel bebas. Dalam penelitian ini yang menjadi variabel dependen ( $\mathrm{Y}$ ) adalah kinerja karyawan

\section{Uji Validitas dan Reliabilitas Instrumen Uji Validitas}

Uji validitas dilakukan untuk mengukur apakah data yang telah didapat setelah penelitian merupakan data yang valid dengan alat ukur yang digunakan (kuesioner). Bila koefisien korelasi (r) lebih besar dari $r$ tabel $(0,361)$, maka pertanyaan tersebut dikatakan valid. Tetapi apabila koefisian korelasi (r) lebih keci dari $r$ tabel $(0,361)$ maka dinyatakan tidak valid. Instrumen yang dibuat sebelum disebar kepada responden yang menjadi sampel penelitian harus dilakukan uji validasi melalui analisis faktor dengan bantuan SPSS.

\section{Uji Reabilitas}

Menurut sugiyono (2016:172) reabilitas instrumen adalah kejituan atau ketepatan instrument pengukur. Uji reabilitas dilakukan untuk mengetahui konsistensi dan ketepatan pengukuran, apabila pengukuran dilakukan pada obyek sama berulang kali dengan instrument yang sama. Untuk memutuskan instrument itu reliable atau tidak maka ketentuanya adalah nilai Cronbach Alplha > 0,600.

\section{Teknik Analisis Data}

Teknik analisis data yang digunakan dalam penelitian ini adalah regresi linier berganda. Analisis regresi linier berganda dilakukan untuk mengetahui pengaruh variabel independen terhadap variabel dependen Regresi berganda digunakan jika terdapat satu variabel dependen dan dua atau lebih variabel independen. Rumus analisis regresi linier untuk menguji hipotesis-hipotesis adalah sebagai berikut:

$\mathrm{Y}=\mathbf{a}+\mathrm{b} 1 . \mathrm{X} 1+\mathrm{b} 2 . \mathrm{X} 2+\mathrm{e}$

Dimana :

$\mathrm{Y} \quad=$ Kinerja Karyawan 


$\begin{array}{ll}\mathrm{a} & =\text { Konstanta } \\ \mathrm{b} 1-\mathrm{b} 2 & =\text { Koefisien Regresi } \\ \mathrm{X} 1 & =\text { Pelatihan } \\ \mathrm{X} 2 & =\text { Insentif } \\ \mathrm{e} & =\text { Faktor Gangguan }\end{array}$

\section{HASIL PENELITIAN DAN PEMBAHASAN}

Interpretasi hasil dalam penelitian ini memberikan penjelasan mengenai hasil penelitian dan dilengkapi dengan penjelasan tentang fenomena pengaruh pelatihan kerja dan pemberian insentif terhadap kinerja karyawan Ellena Skin Care Solo.

\section{Pengaruh Pelatihan Kerja terhadap Kinerja Karyawan}

Hasil perhitungan untuk variabel pelatihan $\left(\mathrm{X}_{1}\right)$ diperoleh nilai $\mathrm{t}_{\text {hitung }}$ sebesar 1,724 . Berdasarkan perhitungan pada signifikansi $10 \%$ nilai $t_{\text {hitung }}$ lebih besar dari $t_{\text {tabel }}(1,724>1,703)$ dengan probabilitas $0,096<0,10$; maka $\mathrm{H}_{0}$ ditolak dan $\mathrm{H}_{1}$ diterima yang berarti bahwa pelatihan kerja berpengaruh signifikan terhadap kinerja karyawan. Hal ini disebabkan Ellena Skin Care Solo merupakan sebuah perusahaan yang bergerak di bidang jasa perawatan tubuh dan wajah, sehingga setiap karyawan yang bekerja di Ellena Skin Care Solo senantiasa mendapatkan pelatihan kerja untuk memberikan bekal keterampilan bagi karyawan dalam memberikan pelayanan jasa kepada pelanggan, sehingga $\mathrm{H}_{1}$ yang menyatakan bahwa pelatihan kerja berpengaruh positif terhadap kinerja karyawan Ellena Skin Care Solo diterima.

Hasil penelitian ini didukung oleh penelitian Crhistian Sinaga yang menunjukkan bahwa secara parsial pelatihan berpengaruh positif dan signifikan terhadap kinerja karyawan. Pelatihan adalah proses mengajarkan karyawan baru atau yang ada sekarang, ketrampilan dasar yang mereka butuhkan untuk menjalankan pekerjaan mereka. Pelatihan merupakan salah satu usaha dalam meningkatkan mutu sumber daya manusia dalam dunia kerja. Karyawan, baik yang baru ataupun yang sudah bekerja perlu mengikuti pelatihan karena adanya tuntutan pekerjaan yang dapat berubah akibat perubahan lingkungan kerja, strategi, dan lain sebagainya. Pelatihan juga dapat diartikan sebagai usaha yang terencana dari perusahaan untuk meningkatkan pengetahuan, keterampilan dan kemampuan karyawan. Dengan pelaksanaan pelatihan yang tepat, maka perusahaan diharapkan dapat memperbaiki efektivitas kerja karyawan dalam mencapai hasil-hasil kerja yang telah ditetapkan (Dessler, 2009).

Pelatihan dalam suatu perusahaan diharapkan dapat mengetahui karakteristik karyawan pada suatu perusahaan dan untuk memberikan pengetahuan tentang teknologi baru serta diharapkan karyawan dapat memiliki respon yang cepat terhadap kemajuan teknologi yang baru. Dengan adanya pelatihan perusahaan diharapkan dapat memberikan stabilitas perusahaan dan karyawan.

\section{Pengaruh Insentif terhadap Kinerja Karyawan}

Berdasarkan hasil perhitungan untuk variabel insentif $\left(X_{2}\right)$ diperoleh nilai $t_{\text {hitung }}$ sebesar 0,613 . Oleh

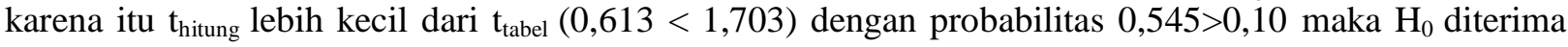
dan $\mathrm{H}_{2}$ ditolak, yang berarti bahwa insentif tidak berpengaruh signifikan terhadap kinerja karyawan Ellena Skin Care Solo, hal ini disebabkan pemberian insentif merupakan hal wajar diperoleh oleh setiap karyawan yang berprestasi dalam bekerja, namun secara umum insentif mempunyai nilai yang tidak cukup besar, karena insentif hanya merupakan tambahan kesejahteraan kepada karyawan yang mempunyai porsi kerja lebih besar, artinya untuk mendapatkan insentif, karyawan diwajibkan untuk bekerja dengan tambahan waktu atau porsi pekerjaan yang lebih besar, hal ini dianggap pemberian insentif hanya sebagai pengganti uang lelah, sehingga $\mathrm{H}_{2}$ yang menyatakan bahwa pemberian insentif berpengaruh positif terhadap kinerja karyawan Ellena Skin Care Solo ditolak.

Pemberian insentif merupakan salah satu hal pokok yang harus diperhatikan oleh setiap perusahaan. Peningkatan pada kinerja karyawan bisa disebabkan oleh besar kecilnya insentif yang diterima, apabila karyawan tidak mendapatkan insentif yang sesuai dengan besarnya pengorbanan dalam bekerja, maka karyawan tersebut cenderung malas bekerja dan tidak bersemangat yang ada akhirnya mereka bekerja semaunya tanpa ada kepuasan kerja yang memadai, yaitu sebagaimana diharapkan oleh karyawan tersebut. Hal inilah yang menyebabkan pemberian insentif tidak selalu berdampak pada peningkatan kinerja karyawan. Insentif yang bervariasi baik yang bersifat finansial, maupun non finansial sangat baik diterapkan di dalam perusahaan, sebab insentif dapat memberikan rangsangan atau motivasi bagi karyawan untuk meningkatkan kinerja agar lebih baik (Putra dan Susanti, 2019: 6).

Penelitian tidak sejalan dengan penelitian yang dilakukan oleh Aldina Nursanti yang menunjukan bawa terdapat pengaruh yang positif dan signifikan antara insentif terhadap kinerja karyawan. Pada 
praktiknya masih ada karyawan yang sudah diberikan insentif akan tetapi kinerjanya juga masih kurang baik.

\section{PENUTUP}

\section{Kesimpulan}

Berdasarkan pembahasan yang telah penulis bahas di bab-bab diatas maka dapat diambil kesimpulan sebagai berikut :

1. Pelatihan kerja berpengaruh signifikan terhadap kinerja karyawan, hal ini disebabkan Ellena Skin Care Solo merupakan sebuah perusahaan yang bergerak di bidang jasa perawatan tubuh dan wajah, sehingga setiap karyawan yang bekerja di Ellena Skin Care Solo senantiasa mendapatkan pelatihan kerja untuk memberikan bekal keterampilan bagi karyawan dalam memberikan pelayanan jasa kepada pelanggan.

2. Hasil penelitian menunjukkan bahwa insentif tidak berpengaruh signifikan terhadap kinerja karyawan Ellena Skin Care Solo, hal ini disebabkan pemberian insentif merupakan hal wajar diperoleh oleh setiap karyawan yang berprestasi dalam bekerja, namun secara umum insentif mempunyai nilai yang tidak cukup besar, karena insentif hanya merupakan tambahan kesejahteraan kepada karyawan yang mempunyai porsi kerja lebih besar, artinya untuk mendapatkan insentif, karyawan diwajibkan untuk bekerja dengan tambahan waktu atau porsi pekerjaan yang lebih besar, hal ini dianggap pemberian insentif hanya sebagai pengganti uang lelah. Peneltian ini tidak

\section{Saran}

Setelah penulis melakukan penelitian maka penulis dapat setidaknya memahami dan dapat menggambarkan penelitian yang sudah dilakukan sehingga, penulis mempunyai beberapa saran diantaranya:

1. Bagi perusahaan

a. Perusahaan diharapkan untuk dapat meningkatkan kinerja karyawan dengan memberikan pelatihan kerja lebih intens atau berkala sehingga, kemampuan karyawan dalam menjalankan tugas pekerjaan perusahaan dapat dikerjakan dengan lebih baik dan dapat memuaskan konsumen.

b. Perusahaan perlu memberikan pelatihan kepada karyawan agar perusahaan lebih memahami karakteristik karyawan dalam hal memperbaruhi kemampuan karyawan dan membantu mereka dalam hal beradaptasi terhadap teknologi baru.

c. Perusahan diharapkan melakukan penilaian secara adil terhadap pemberian insentif yang disesuaikan dengan kinerja karyawan, insentif yang memuaskan sehingga mampu meningkatkan kinerja karyawan adalah yang dilakukan secara adil sesuai dengan kinerja karyawan.

2. Bagi penelitian selanjutnya

Penulis berharap penelitian selanjutnya untuk dapat memperluas variabel penelitian sehingga topik yang dibahas lebih beragam dan informasi-informasi yang diberikan akan lebih lengkap

\section{DAFTAR PUSTAKA}

A. A. Anwar Prabu Mangkunegara. 2006. Evaluasi Kinerja Sumber Daya Manusia. Jakarta: Refika Aditama.

B. Romney, Marshal \& Paul John Steinbart, 2005. Accounting Information System di Indonesiakan oleh Dewi Fitriasari \& Deny Amos Kwary. Jakarta : Salemba Empat

Dessler, Gary. 2009. Manajemen SDM : buku 1. Jakarta: Indeks.

Dharmmesta, Basu Swasta dan Hani Handoko, 1997. Manajemen Pemasaran Analisa Konsumen. Edisi Pertama. Yogyakarta : BPFE.

Edwin B. Flipo. 1996. Manajemen Personalia, Edisi. Keenam, Jakarta: Erlangga.

Fandy, Tjiptono, 2000. Manajemen Jasa, Edisi Kedua. Andy offset, Yogyakarta

Ghozali, I. 2009. Aplikasi Analisis Multivariate dengan Program IBM Eviews 8. Semarang: Universitas Diponegoro.

Ghozali, Imam. 2016. Aplikasi Analisis Multivariete Dengan Program IBM SPSS 23 (Edisi 8). Cetakan ke VIII. Semarang : Badan Penerbit Universitas Diponegoro 
Hasibuan, Malayu S.P. 2009. Manajemen: Dasar, Pengertian, dan Masalah. Edisi Revisi. Jakarta : Bumi Aksara

Kamus Bahasa Indonesia edisi empat, Hal 708. Jakarta: PT. Gramedia; diakses Maret 2015

Kotler, Philip dan Gary Amstrong. 2006. Manajemen Pemasaran 2, Edisi Ke 12 Jilid 1, New Jersey. Indeks

Kusnanto, Dwi, Analmateris Pengaruh Kompetensi dan Motivasi Kerja Terhadap Kinerja Pegawai di PT. PLN (Persero) APJ Mojokerto, Thesis, (Universitas Brawijaya, Malang. 2007), h.37

Lupiyoadi, Rambat. 2001. Manajemen Pemasaran Jasa, Edisi Pertama: Teori dan Praktik. Jakarta : Salemba Empat

Lupiyoadi, Rambat. 2013. Manajemen Pemasaran Jasa Berbasis Kompetensi (Edisi 3). Jakarta: Salemba Empat.

Marlina. Endy, 2008, Panduan Perancangan Bangunan Komersial. Andi Offset, Yogyakarta

Mardiasmo. 2002. Akuntansi Sektor Publik. Yogyakarta : Penerbit Andi.

Marzuki, S. M. 2012. Pendidikan Nonformal : Dimensi dalam Keaksaraan Fungsional, Pelatihan, dan Andragogi. Bandung: PT Remaja Rosdakarya

Meldona dan Siswanto. 2011. Perencanaan Tenaga Kerja. Malang : UIN Maliki Press, 2011

Moenir, A.S. 2010. Manajemen Pelayanan Umum Di Indonesia. Jakarta : Bumi Aksara

Noe, R.A., Hollenbeck, J.R., Gerhart, B., Wright, P.M. 1994. Human Resource Management : Gaining a Competitive Advantage. Illnois : Austen Press.

Nugroho, S; Haryono, A.T. dan Hasiolan, L.B. 2017. Pengaruh Pelatihan Kerja, Motivasi dan Pemberian Insentif terhadap Kinerja Pegawai Dinas Pertanian Kota Semarang. Semarang: Fakultas Ekonomi, Universitas Pandanaran Semarang.

Rizki, A. B; Saryadi dan Dewi, R.S. 2014. Pengaruh Pelatihan dan Insentif terhadap Kinerjaa Karyawan Bagian Marketing PT. Nasmoco Gombel Semarang. Semarang: Fakultas Ilmu Sosial dan Ilmu Politik, Universitas Diponegoro.

Sjafri Mangkuprawira. 2011. Manajemen Sumber Daya Manusia Stratejik, Bogor : Ghalia Indonesia.

Sugiyono. 2009. Metode Penelitian Bisnis. Bandung: CV Alberta.

Sugiyono. 2012. Metode Penelitian Kuantitatif Kualitatif dan $R \& D$. Bandung: Alfabeta.

Sugiyono. 2013. Metode Penelitian Pendidikan Pendekatan Kuantitatif, Kualitatif, dan $R$ \& D. Bandung: Alfabeta.

Sugiyono. 2016. Metode Penelitian Kuantitatif, Kualitatif dan R\&D. Bandung: PT Alfabeta.

Zeithaml. VA. Bitner MJ. 1996. Delivering and Performing Service. Part Five. Service Marketing, International Ed., The McGraw-Hill Companies, Inc 